UDC 711.16:504.75

DOI 10.36622/VSTU.2022.53.1.008

E. V. Kokorina ${ }^{1}$

\title{
SPACE OF CONCEPTUAL CREATIVITY BASED ON ARCHITECTURAL DESIGN
}

\author{
Voronezh State Technical University ${ }^{1}$ \\ Russia, Voronezh
}

\begin{abstract}
${ }^{1}$ PhD in Engineering, Assoc. Prof. of the Dept. of Theory and Practice of Architectural Design, tel.: +7 (4732) 71-54-21, e-mail:lenakokorina@mail.ru
\end{abstract}

\begin{abstract}
Statement of the problem. The concept of "conceptual creativity space" lying at the heart of architectural design is examined, which combines important theoretical components for variant development and the formation of the main idea of a project.

Results. Within the framework of the theoretical and methodological foundations of the process of architectural design, the model "Energy Frame of Design Creativity" is presented. For the creative development of the artistic and emotional component of the idea at the stage of creative search, the model "Space of conceptual creativity" is set forth.

Conclusions. The article looks at the theoretical aspects necessary for the integrated development of the architectural idea of a project at the stage of creative search for use in educational architectural design.
\end{abstract}

Keywords: architecture, conceptual creativity, architect's creative method, idea, rational and irrational, creative thinking.

Introduction. The development of architectural design in the context of global cultural integration is constantly experiencing metamorphoses in cognitive and creative terms. According to O.V. Orelskaya, in the development of global architecture, the following polar directions currently dominate: "regional and global, traditional and innovative, irrational and rational" [19, p. 532].

Architecture is a multilayer system that combines a layer of scientific research and theoretical developments, a layer of virtual images and creative concepts, a layer of inventions and projects for the practical implementation of design solutions, notes A.V. Korotich [16]. In theoretical studies M.V. Dutseva regards the process of architectural design as a multi-basic creative synthesis that conveys the author's vision of the world, the creative method and the author's personality traits in the resulting object [6]. Yu.I. Karmazin emphasizes that the archi-

(C) Kokorina E. V., 2022 
tect's creative method emerges as a cumulative principal model of the architect's work which has flexible differentiation and integrity $[8,9]$.

In connection with the relevance of introducing fundamentally new approaches to architectural education, this article discusses the concept of "conceptual creativity space", formed by the foundations of the architect's creative method, which combines a number of important components for the integrated development of the main idea of an architectural work. This topic is relevant today for the study of the creative basis for the development of an idea at the stage of creative search at the basis of architectural design within the framework of the educational process. Consideration of the basics of visualization in integration interaction with the creative method of an architect is reflected in the aesthetics of graphic concepts for creating an image of an architectural object in the works of great architects, masters of the past and in the work of the world's leading architects of the 21 st century. The results of the introduction of theoretical development in the conceptual section of the diploma design are presented.

1. Theoretical and methodological foundations of architectural design. The architectural design methodology entails a wide range of techniques, principles and methodological approaches whose synthesis ensures the development of creative thinking and the epitomy of the concept of an idea in a sketch in design modeling.

According to a study of the history of architecture, an important design factor was a graphic search, which represents the process of „birth, development and formation of an architectural image“ [18, p. 3].

The great works by the Renaissance masters are indicative of the relationship of philosophical and scientific thought with the foundations of architectural theory while creating an architectural piece. In the works by Leon Battista Alberti, Averlino Filarete, Filippo Bruneleschi, Leonardo da Vinci, the solid foundations of the creative method are laid, i.e., "they lay the foundations for professionalism of architecture, since as artists, they were also brilliant thinkers who broke through the barrier that had cut off art from scientific knowledge" (Fig. 1-2) [7, p. 22].

The theoretical works of the following authors are currently devoted to the methodological foundations of architectural design and the issue of the architect's creative method: B. G. Barkhin, I. G. Lezhava, V. L. Khait, V. L. Glazychev, A. E. Korotkovsky, A. V. Stepanov, D. L. Melodinsky, G. I. Ivanov, F. T. Martynov, S. P. Zavarikhin, Yu. I. Karmazin, L. P. Kholodov, etc. Artistic aspects of creativity in architecture are dealt with in the studies by A. G. Gabrichevsky, G. B. Borisovsky, A. A. Tits, M. S. Kagan, Z. N. Yargina, A. V. Ikonnikov, G. N. Lavrik, T. F. Savarenskaya, V. F. Markuzon, V. I. Iovlev, A. E. Korotkovsky, M. V. Dutsev, etc. 


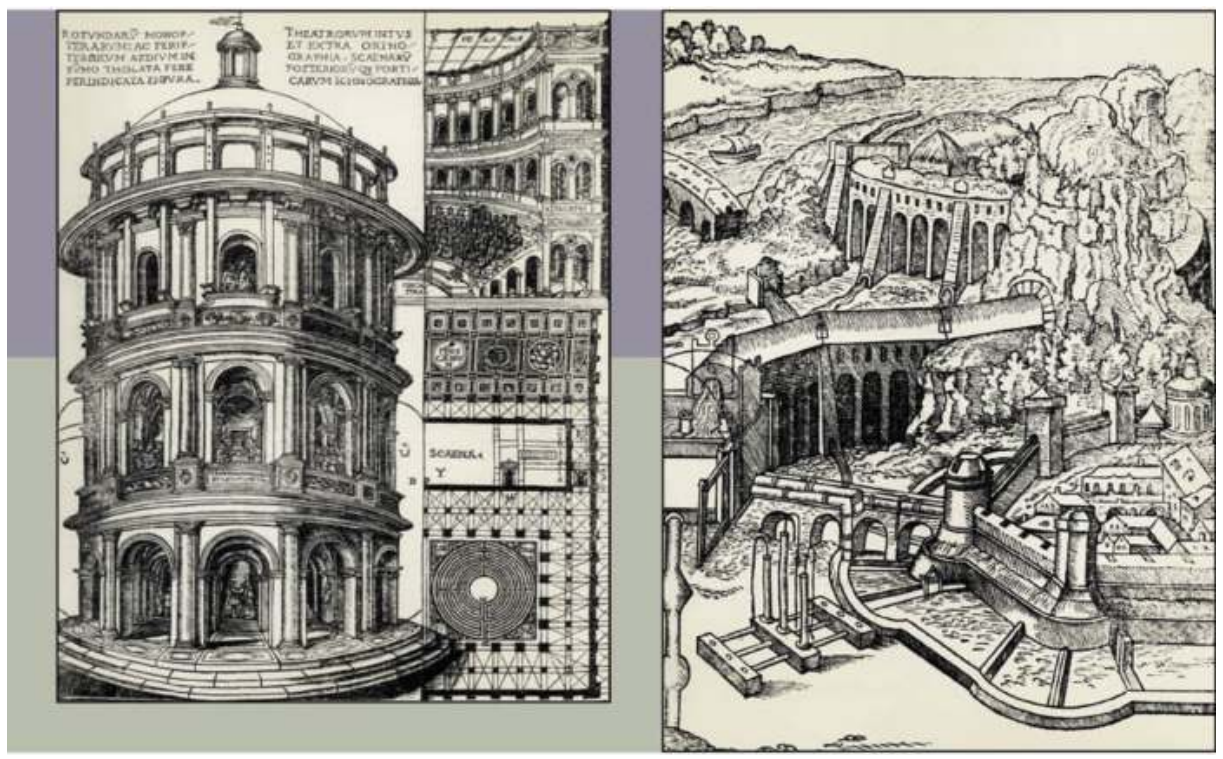

Fig.1. Averlino Filarete. Drawing from the treatise. Facade, layout and interior of a civil centric building (c. 1400-1470) [20, p. 341]; Leon Battista Alberti (1404-1472). Illustration from the treatise. Engineering fortifications of an ideal city [20, p. 339]
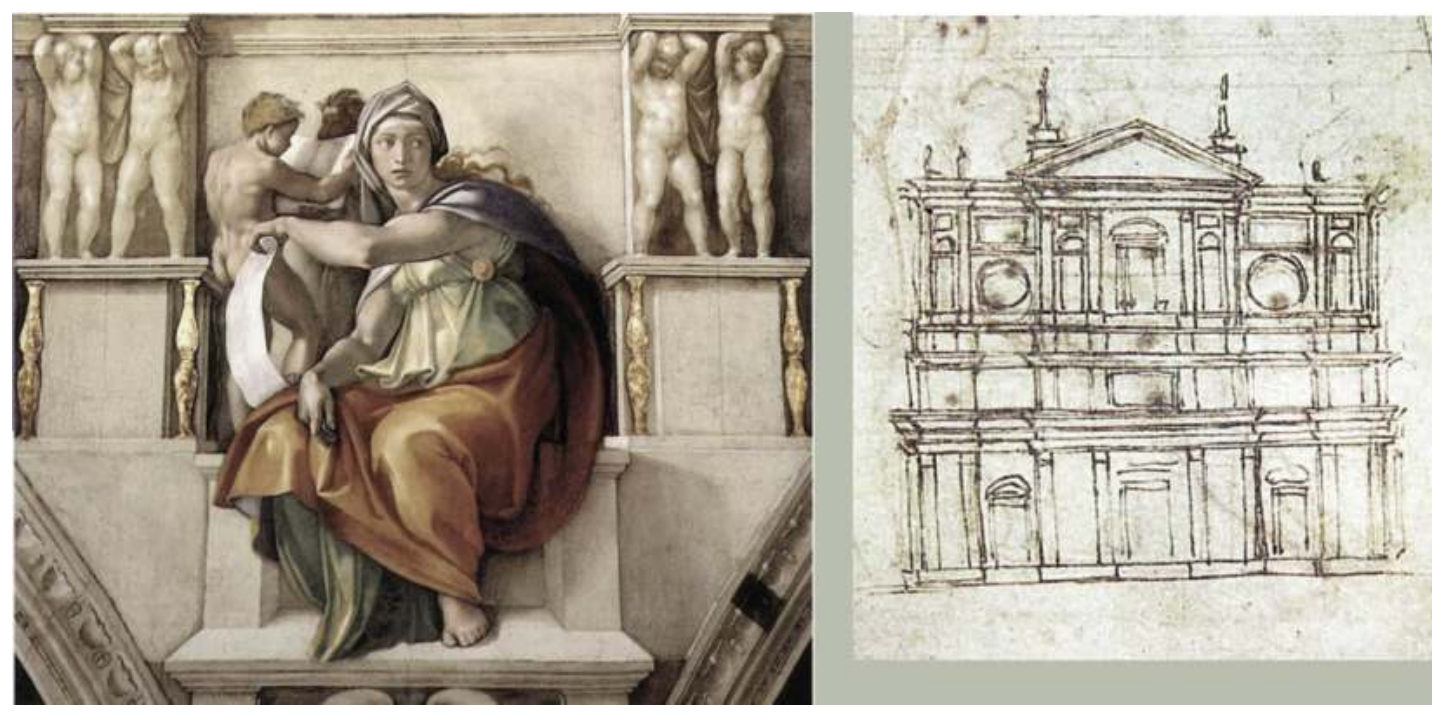

Fig. 2. Michelangelo. The Delphic Sibyl, a fragment of the painting in the Sistine Chapel. Vatican, Rome; sketch of the facade of San Lorenzo, Florence. 1517 [28, p. 47, 104]

As pointed out by G.N. Aidarov, in educational architectural design "the methodology of advanced innovative architectural thinking should be made an integral part of the educational process" [1]. Graphic interpretation of images can manifest itself in ambiguity, the search for the major vector of the development of the idea. Thus according to Ch. Jencks, the informational and associative-figurative "layers" of modern architectural creativity are indicative of the aesthetics of the symbolic nature of the architectural idea [5], reflect the specifics of the artistic concept in the works of the great architects of the 20th century, e.g., Le Corbusier the search for the artistic image of the chapel in Ronchamp, J. Utson - the idea of an opera 
theater in Sydney, F. Gehry - sculptural plasticity of the image of the Guggenheim Museum in Bilbao, etc. (Fig. 3-5).

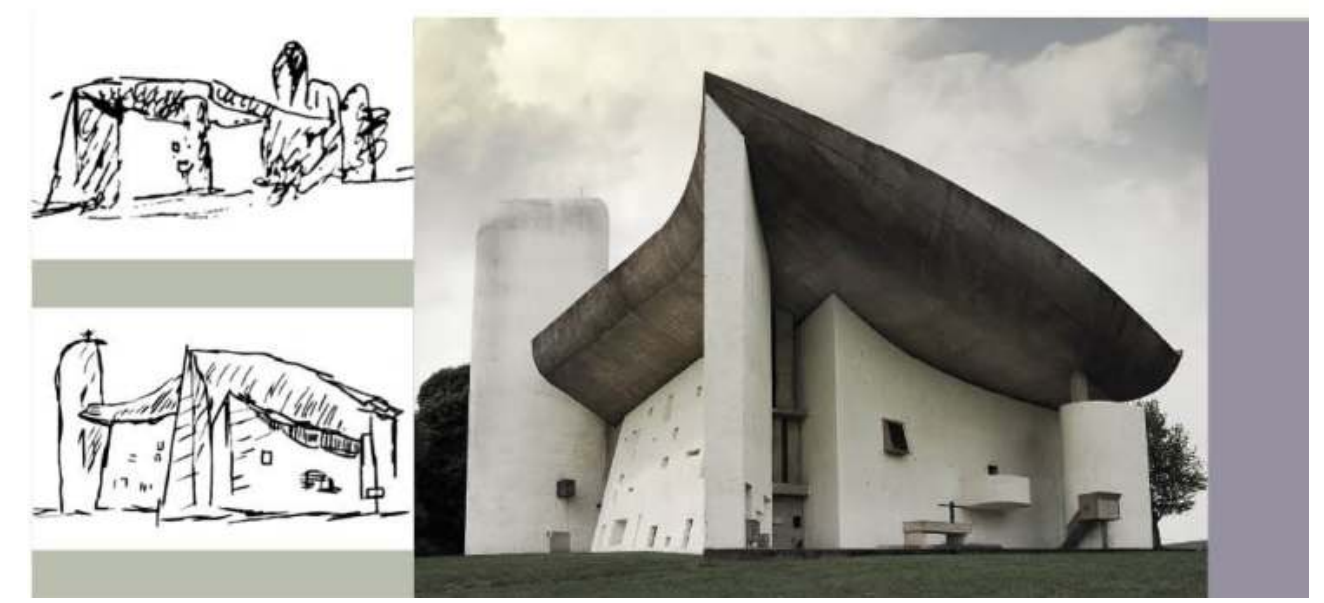

Fig. 3. Architect Le Corbusier. Chapel in Ronchamp. France. 1950—1954 Sketches and appearance [17, p. 211]

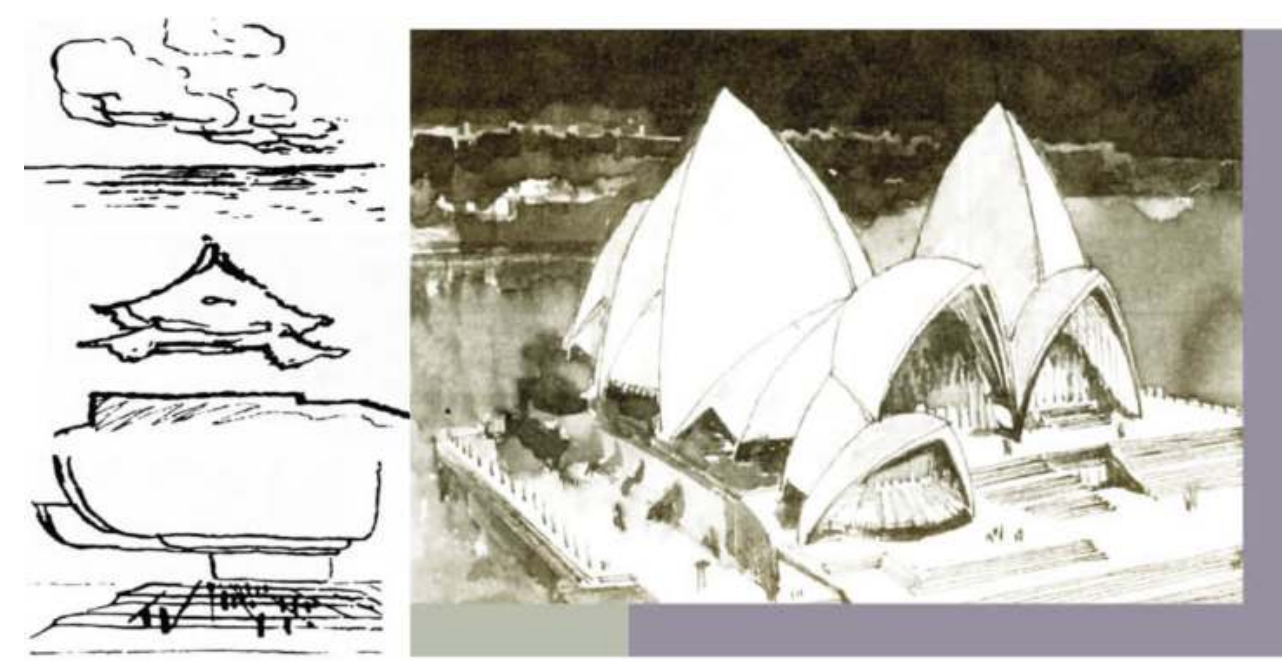

Fig. 4. Architect Jorn Utzon. Sketches for the project of the Opera House building in Sydney. 1956 [18, p. 174 - 175]

Let us consider the process of architectural design as a complex scientific and theoretical study. Due to the interaction of the four major methods: the artist (reflecting the personal creative vision of the author); scientist (forming the ability to constant analysis-synthesisgeneralization); engineer (reflecting the structure of thought), identified by B. G. Barkhin [3, p. 39] and the philosophical and ideological method (combining the components into a meaningful and purposeful integrity) set forth by Yu. I. Karmazin [8, p. 75] ensures the methodological efficiency of creative search. The directions of development of architectural creativity that impact the formation of the energy framework of the architect's creative method are the following foundations: information-analytical, scientific-theoretical, constructivetechnological, compositional-artistic, environmental, socio-economic, etc. 


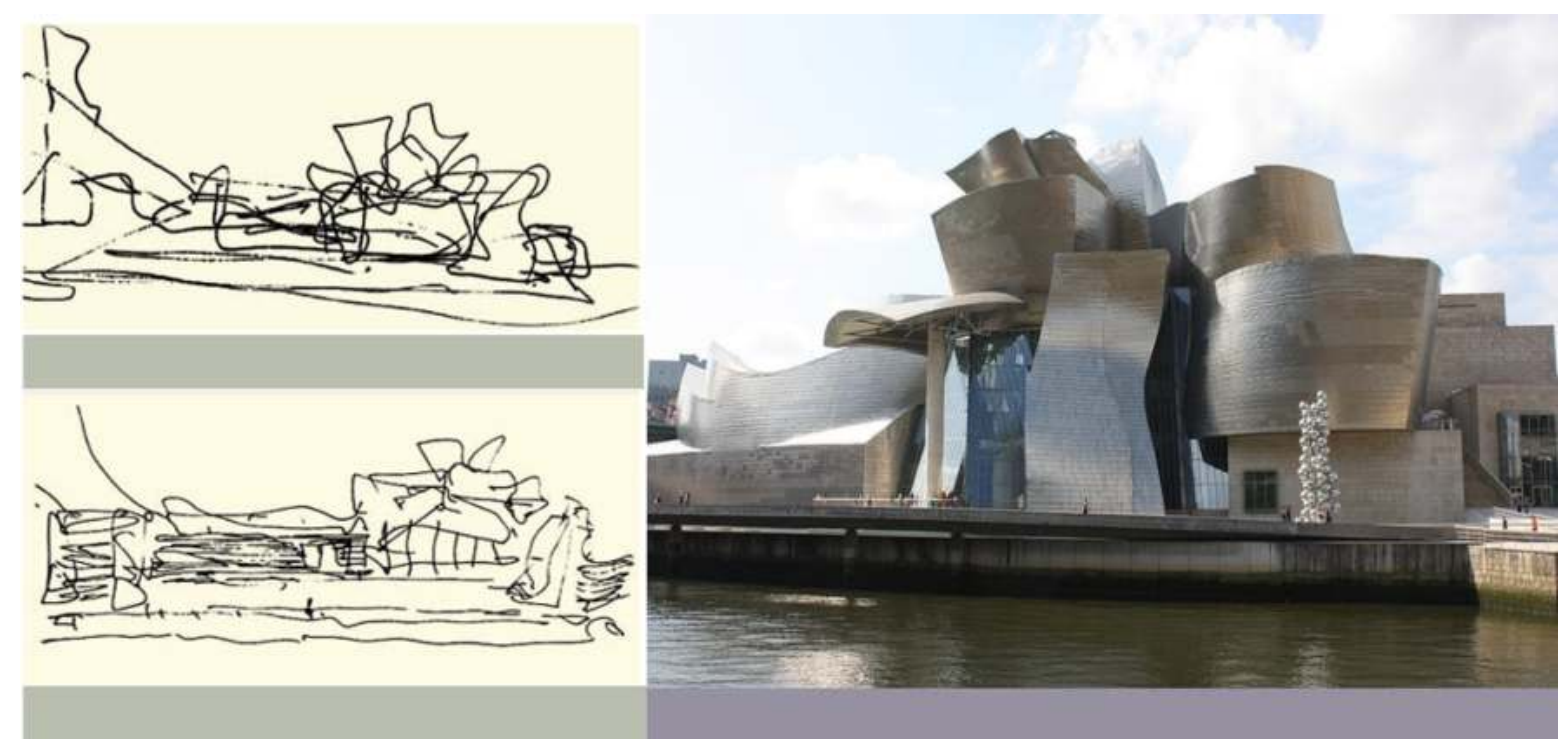

Fig. 5. Architect F. Gary.

Sketches for the design of the building of the Guggenheim Museum in Bilbao [4]

The author has developed the model „Energy Frame of Design Creativity“ for exploring the artistic and emotional component of the concept of translating an idea into a sketch (Fig. 6). To this end, the interaction of irrational and rational components that form a continuous search for new creative solutions on the path of development of the design model of an object is considered at the heart of the "energy" framework of design creativity. This principle underpins the development of ,intellectual strategies“ that characterize the „dual nature of the creative process" at the heart of educational design [15, p. 52]. As part of the theoretical and methodological foundations of the process of architectural design, the author suggested that three major components are identified: methodology, psychology of creative thinking and drawing, clearly showing the properties of the visual language of the architect's creative method [10]. The three suggested directions of search show the gradual improvement of the idea through the stages of tactical and strategic development of the design modeling process [10], the interaction of visual and semantic forms of communication that allow one to translate the thought into a graphic form of the image through the emotional-tectonic code of the architectural drawing [13]. The whole variety of graphic sketches will constitute a dynamic search for an architectural idea, i.e., the space of conceptual creativity. The emergence of new figurative forms is an integral element in the creative quest of every architect, it is also a reflection of the creative individuality of the author resulting in the development of the art of architecture. Thus the conceptual approach represents the unity of the idea at the philosophical and worldview level and its object-spatial epitomization [10]. 


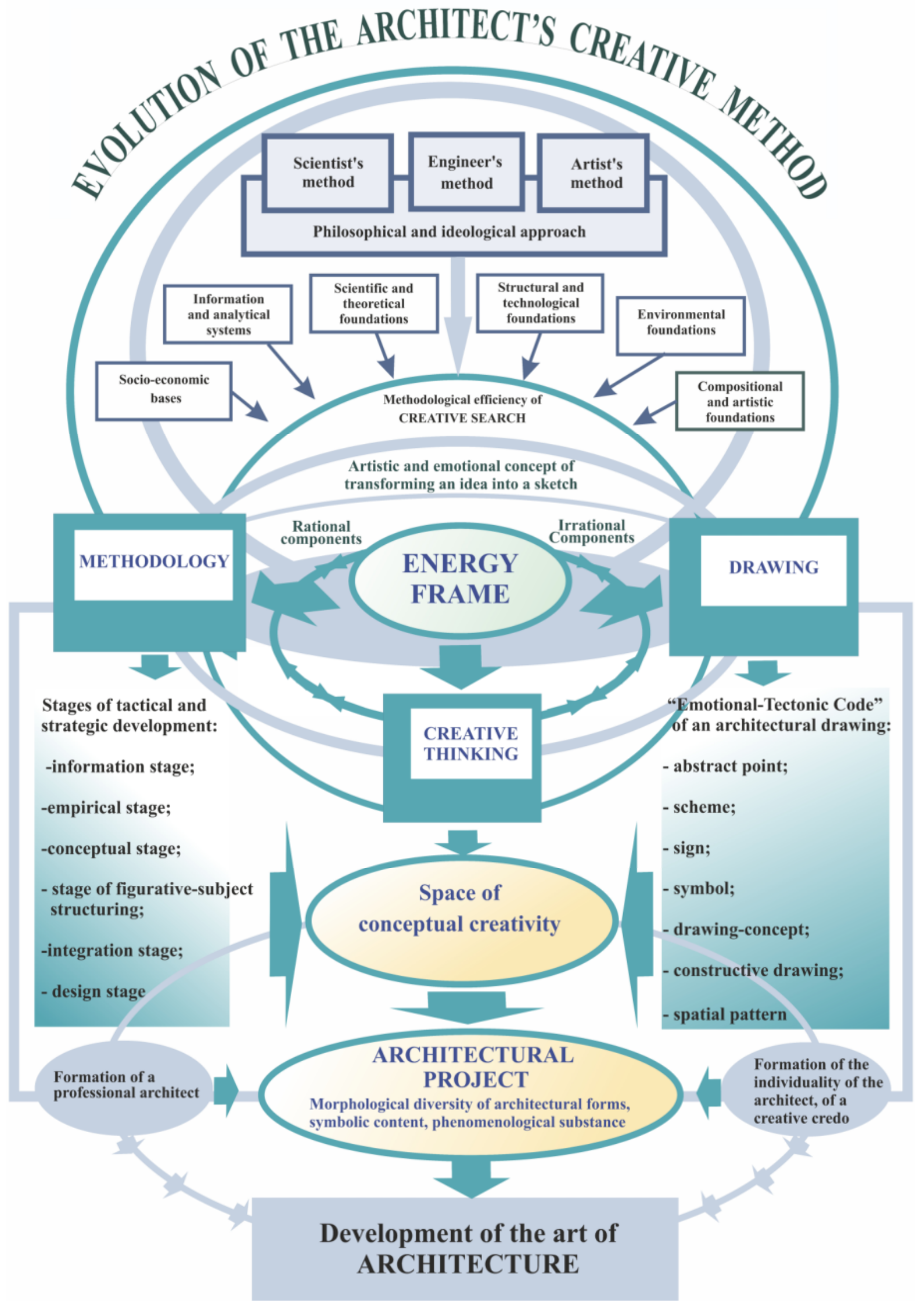

Fig. 6. „Energy Frame of Design Creativity“ model 
2. The space of conceptual creativity. The principles and laws of philosophy, science and art play a key role in the development of architectural creativity which are a theoretical basis for understanding architectural creativity as a universal conceptual space of ideas and images.

The space of conceptual creativity combines, a lot of components for the complex development of the idea of an architectural work" [12, p. 91]. The variability of the architectural drawing turns the idea into an associative-figurative theme of the image. "The language of the communicative space of the creative process is the emotional and sensual side of the architectural design when creating original compositions of visual images..." [11, p. 126].

Through the course of developing the topic, the author suggests that several important theoretical components for the conceptual development and formation of an architectural idea are identified: thinking, image, space, time [12]. For the development and creation of the architectural idea of the project, a hypothesis of the formation of a „,conceptual creativity space“" was set forth (Fig. 7).

The process of architectural design is a complex synthesis of part of ,sensual creativity“ and a rational approach [24, p. 408]. A difficult issue for design creativity is the „mechanism“ of the thinking process, i.e., equivalent to the „mechanism“ of the formation of the idea, development, implementation of creative thought. For example, the structural and logical method is at the heart of Kenzo Tange's creativity [26], and the artistic-compositional method is central to Renzo Piano's design decisions of [29]. The concept of architectural thought or creative thinking is crucial for modern architectural science. A. G. Rappaport identifies three types of architectural thinking: design, figurative (artistic) and normative-organizational [22]. The interaction of different types of thinking is combined into a complex mechanism of thinking that regulates the integrity of creative search in the process of creating an idea in a sketch form or verbal construction. The emotional component is vital in addressing creative problems [27]. The model includes the major types of thinking that connect two sides of a single process that are actively involved in the implementation of the author's idea: intuitive-logical, rational-irrational, subjective-objective, divergent-convergent, etc.

The subtlety of perception and the plasticity of thinking, facing the world of fantasy, develop with the parallel work of such types of thinking as associative, abstract, philosophical, figurative, three-dimensional, artistic, etc. [10]. For the development of intuitive and logical, irrational and rational beginnings of the search in the creative process, it is important that an idea in a drawing is epresented, fixed and depicted. 


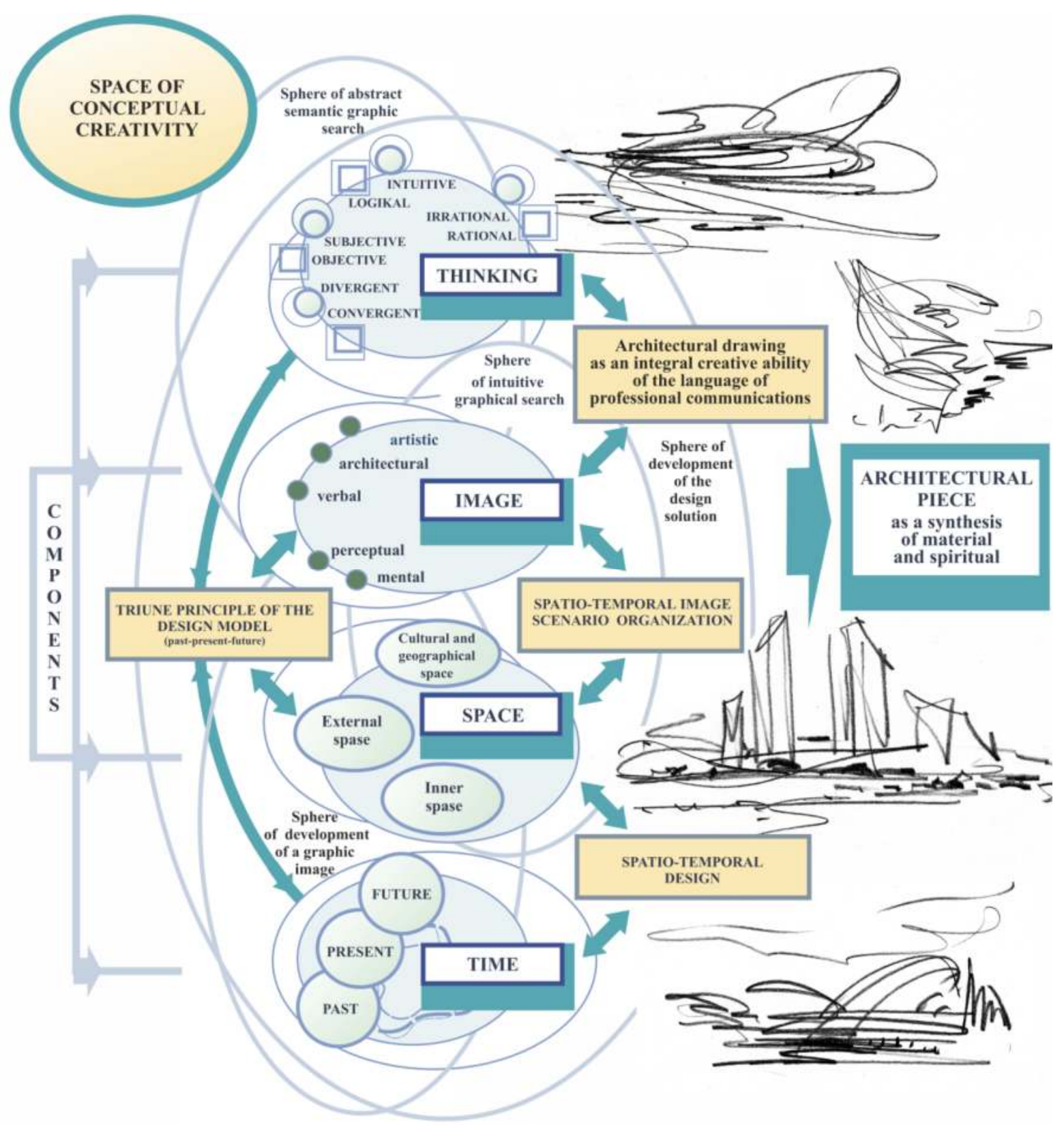

Fig, 7. „Space of Conceptual Creativity“ model. Drawings by the author

Depending on the context, the concept of an „image“ has several meanings: perceptual, mental, artistic, architectural, verbal one. "Famous architects' drawings are considered an independent work of art", which are filled with metaphorical images and associations [12, p. 93]. They reflect the virtuosic embodiment of the thinking process, the emergence of an idea and its development, revealed on graphic sheets and paintings, representing the principle of "graphic" research, i.e., the core of the architectural design methodology. The philosophy of searching for the concept of the architectural image of a future object is represented by drawings and sketches by the outstanding modern architects: S. Calatrava, Z. Hadid, R. Piano, 
E. O. Moos, M. Fuksas, A. Isozaki, S. Kuznetsov, S. Choban, etc. “A high-quality architectural design is key to high-quality architecture," notes Sergei Kuznetsov, Chief Architect of Moscow [2]. He emphasizes that the semantic artistic and emotional potential of an architectural drawing has a major role to play in shaping the individuality and an architect's creative credo. "The conceptual orientation of creative activity is based on the structural sequence of stages in the development of an idea having their own laws and principles of the art of building an architectural composition, means and graphic techniques" [14, p. 148].

Given the process of creative search, the author's idea receives a variant representation in the artistic space of the image for the existence and phased development in spatio-temporal design. The time parameter is represented by three modes of time: past - present - future. The integrity of the development of a project idea can be developed through the content of these concepts. Acquaintance with the "past" reveals the specifics and style of historical and architectural forms of building, the spirituality of the environment, traditions, worldview, etc. The modern level, i.e., the "present", provides information about the existing typology of buildings, the emotional and tectonic content of architecture, social and conomic conditions, structural systems, the level of technology development, etc. The concept of "future" makes it possible to seek new methods of shaping, principles for the development of architectural space, figurative and stylistic brightness of new artistic solutions, etc. [9].

The patterns of space modeling combine a large number of categories and principles involved in shaping the idea of creating and solving cultural-geographical, external and internal space. These days in architectural practice, the topic of spatio-temporal design is urgent since "the unity of time and space lends the architectonic appearance a new and completely plastic aspect" [21, p. 278]. The method of compositional-spatial modeling lies at the heart of the mo-dern shaping paradigm filling design solutions with new figurative and semantic characteristics [25].

One of the major tasks of educational activity is to uncover of the student's creative potential, the formation of his creative personality, conceptual thinking. As a result of the use of the author's methodology in training sessions, its effectiveness was confirmed at the stage of creative search: in the process of making sketches by students, the emotional and semantic basis of the image was embodied in the compositional plasticity and dynamism of the image, the strength and character of the line conveying the idea $[10,12,13]$. This can be seen as an experimental component of the creative design process where the architectural drawing embodies the integral creative ability of the professional communications language space (Fig. 8). 


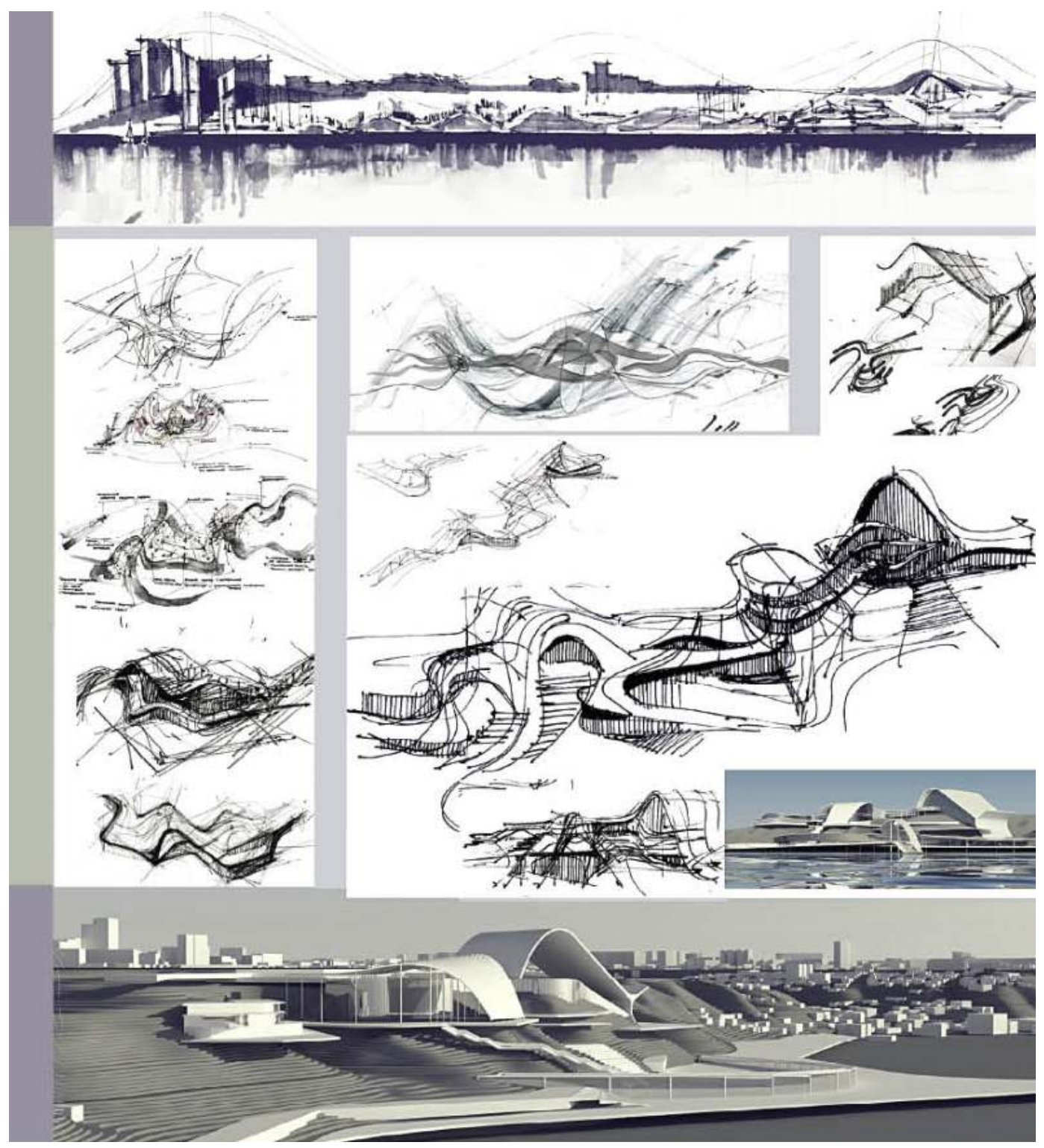

Fig. 8. Conceptual search for the artistic image of the "Cultural and Public Complex on Petrovskaya Embankment in the City of Voronezh”. Completed by: VSTU student L. V. Bobylkina. Research supervisor: E. V. Kokorina [10, p. 178]

Conclusions. This theoretical development relies on studies of the basics of design creativity, types of creative thinking, initiating creativity, forming a whole field of associations necessary for a variant search for an architectural idea of a project. The article suggests that the artistic and emotional component of the idea through the architectural drawing at the stage of creative search through the space of conceptual creativity for the development of the architectural design process is developed. In the process of variant sketching, a graphic line of a semantic plot, a scenario concept is developed in an architectural drawing, and the idea is gradually formed into a three-dimensional expression of the major idea of a project which is transferred to the next stage of the project development. 


\section{References}

1 Aidarova G. N. [Ivan Leonidov and architectural strategies of the XXI century]. Problemy arkhitektury, gradostroitel'stva i dizaina : nauch. konf. Kazan. gos. arkhitektur.-stroit. un-ta [Problems of architecture, urban planning and design]. Available at: http://rudocs.exdat.com/docs/index-489378.html?page=5.277

2 Arkhitekturnyi risunok $i$ ego rol'v rabote arkhitektora [Architectural drawing and its role in the work of the architect]. Available at: http://www.archplatforma.ru/?act=1\&nwid=2795 (accessed: 03.12.2021).

3 Barkhin B. G. Metodika arkhitekturnogo proektirovaniya [Methods of architectural design]. Moscow, Stroiizdat Publ., 1982. 224 p.

$4 \quad$ Vsemirno izvestnye zdaniya: muzei Guggenkhaima v Bil'bao [World-famous buildings: Guggenheim Museum in Bilbao]. Available at: https://realt.onliner.by/2011/12/17/po (accessed: 10.10.2021).

5 Dzhenks Ch. Novaya paradigma $v$ arkhitekture [A New paradigm in architecture]. Available at: http://cih.ru/ae/ad37.html.

6 Dutsev M. V. Kontseptsiya khudozhestvennoi integratsii v noveishei arkhitekture [The concept of artistic integration in modern architecture]. N. Novgorod, NNGASU Publ., 2013. 388 p.

7 Zemtsov S. M., Glazychev V. L. Aristotel' F'oravanti [Aristotle Fioravanti]. M., Stroiizdat Publ., 1985. 184 p.

8 Karmazin Yu. I. Tvorcheskii metod arkhitektora: vvedenie v teoreticheskie i metodicheskie osnovy [The creative method of the architect: an introduction to the theoretical and methodological foundations]. Voronezh, Izd-vo Voronezh. gos. un-ta, 2005. 496 p.

9 Karmazin Yu. I. Metodologicheskie osnovy i printsipy proektnogo modelirovaniya : ucheb. posobie po napravleniyu "Arkhitektura" [Methodological foundations and principles of project modeling : textbook. manual in the direction of "Architecture"]. Voronezh, VGASU Publ., 2006. 179 p.

10 Kokorina E. V. Arkhitekturnyi risunok kak integral'naya tvorcheskaya sposobnost' yazyka professional'nykh kommunikatsii [Architectural drawing as an integral creative ability of the language of professional communications]. Voronezh, Al'bom Publ., 2015. 208 p.

11 Kokorina E. V. Arkhitekturnyi risunok kak kreativnaya sostavlyayushchaya yazyka kommunikativnogo prostranstva tvorcheskogo protsessa [Architectural drawing as a creative component of the language of the communicative space of the creative process]. Privolzhskii nauchnyi zhurnal, 2012, no. 1, pp. 120-127.

12 Kokorina E. V. Muzei. Voploshchenie teoreticheskikh kontseptsii [The embodiment of theoretical concepts]. Voronezh, Masterskaya knigi Publ., 2019. 192 p.

13 Kokorina E. V., Dontsov D. G., Kartashova K. K. Osobennosti sozdaniya khudozhestvennogo obraza v protsesse arkhitekturnogo tvorchestva [Features of creating an artistic image in the process of architectural creativity]. Nauchnyi vestnik Voronezhskogo gosudarstvennogo arkhitekturno-stroitel'nogo universiteta. Stroitel'stvo i arkhitektura, 2014, no. 4, pp. 139-146.

14 Kokorina E. V., Chernyshov E. M., Surovtsev I. S. Formirovanie metodologicheskogo instrumentariya arkhitekturnogo risunka [Formation of methodological tools of architectural drawing]. Nauchnyi vestnik Voronezhskogo gosudarstvennogo arkhitekturno-stroitel'nogo universiteta. Stroitel'stvo i arkhitektura, 2014, no. 4, pp. 147-153.

15 Kokorina E. V. Formirovanie u studentov tvorcheskogo podkhoda k issledovatel'skoi i nauchnoi rabote v obrazovatel'nom protsesse [Formation of students' creative approach to research and scientific work in the educational process]. Vestnik Voronezhskogo Gosudarstvennogo universiteta. Seriya «Problemy vysshego obrazovaniya», 2019, no. 1, pp. 50-53.

16 Korotich A. V. Teoreticheskaya model' sovremennoi arkhitektury [Theoretical model of modern architecture]. Akademicheskii vestnik UralNIIproekt RAASN, 2010, no. 1. Available at: https://cyberleninka.ru/article/n/teoreticheskaya-model-sovremennoy-arhitektury (accessed: 27.01.2019).

17 Le Korbyuz'e. Arkhitektura XX veka [Architecture of the XX century]. Moscow, Progress publ., 1977. 303 p.

18 Maksimov O. G. Risunok v arkhitekturnom tvorchestve: Izobrazhenie, vyrazhenie, sozidanie [Drawing in architectural creativity: Image, expression, creation]. Moscow, Arkhitektura-S, 2002. 464 p.

19 Orel'skaya O. V. Arkhitektura kak letopisnyi i esteticheskii portret gorodkogo sotsiuma [Architecture as a chronicle and aesthetic portrait of urban society]. Vestn. Nizhegor. un-ta im. N. I. Lobachevskogo. Ser. «Sotsial'nye nauki». N. Novgorod, 2006, no. 1 (5), pp. 532-536.

20 Osmolovskaya O. V., Musatov A. A. Risunok po predstavleniyu [Drawing by presentation]. Moscow, Arkhitektura-S Publ., 2008. 392 p.

21 Prak Nil's Luning. Yazyk arkhitektury. Ocherki arkhitekturnoi teorii [The language of architecture. Essays on architectural theory]. Moscow, Delo Publ., 2017. 288 p.

22 Rappoport A.G. K ponimaniyu arkhitekturnoi formy. Diss. d-ra iskusstvovedeniya [Towards understanding the architectural form. Dr. of Art History diss.]. Moscow, 2002. $141 \mathrm{p}$.

23 Risunok k proektu: pyat' mnenii o ruchnoi grafike [Drawing for the project: five opinions about manual graphics]. Available at: https://archspeech.com/article/risunok-k-proektu-pyat-mneniy-o-ruchnoy-grafike (accessed: 25.11.2021).

24 Ryabushin A. V. Arkhitektory rubezha tysyacheletii. Kniga vtoraya: Poiski $i$ otkrytiya [Architects of the Turn of the Millennium. Book two: Searches and discoveries]. Moscow, Iskusstvo - XXI vek Publ., 2014. 416 p. 